\title{
Respon tanaman kedelai (Glycine max L. Merill) pada berbagai konsentrasi cemaran ion logam $\mathrm{Ni}^{2+}$ dengan pemberian biokompos
}

\author{
(Response of soybean plants (Glycine $\max$ L.) at various contamination concentrations \\ ion of nickel metal $\left(\mathrm{Ni}^{2+}\right)$ with biocompost application)
}

\author{
R. N. Fitriani, S. Budiyanto, dan Sukarjo \\ Agroecotechnology, Faculty of Animal and Agricultural Sciences, Diponegoro University \\ Tembalang Campus, Semarang 50275 - Indonesia \\ Agricultural Environment Research Center, Pati, Central java \\ Corresponding E-mail: ririnnurf@gmail.com
}

\begin{abstract}
The objective of this research was to study the response of growth, production and quality of soybeans to nickel metal contaminated soils that were given biocompost. The research was conducted at the Screen house and Integrated Laboratory of Agricultural Environment Research Institute (AERI) Pati, Central Java from November 2018 - February 2019. The experimental design used in this study was a completely randomized design of $5 \times 3$ factorial patterns with 3 replications. The first factor was the treatment of the concentration of nickel (Ni) $0,25,50,75,100 \mathrm{ppm}$ and the second factor was the treatment of biocompost doses of 0 tons / ha, 3.5 tons / ha and 7 tons / ha. Data were analyzed by variance analysis and followed by Duncan's Multiple Range Test. The results showed that the soil that was given biocompost less than 7 tons / ha and all levels of contamination showed a decrease in soybean growth and production. Soil that is given 7 tons / ha of biocompost in the treatment concentration of 25 ppm nickel contamination produces soybean production (number of filled pods) equal to or equal to land without nickel contamination. The nickel concentration in soybean seeds on $25 \mathrm{ppm}$ nickel contaminated soil with 7 tons / ha of biocompost is still above the allowable limit.

Keywords: soybeans, nickel contamination, biocompost
\end{abstract}

\begin{abstract}
ABSTRAK
Penelitian bertujuan untuk mengkaji respon pertumbuhan tanaman kedelai, produksi dan kualitas kedelai pada tanah yang tercemar logam nikel yang diberi biokompos. Penelitian dilakukan di Rumah Kasa dan Laboratorium Terpadu BALINGTAN (Balai Penelitian Lingkungan Pertanian) Pati, Jawa Tengah dari bulan November 2018 - Februari 2019. Rancangan dasar yang digunakan dalam penelitian ini adalah rancangan acak lengkap pola faktorial 5 x 3 dengan 3 ulangan. Faktor pertama yaitu perlakuan konsentrasi cemaran nikel (Ni) $0,25,50,75,100 \mathrm{ppm}$ dan faktor kedua yaitu perlakuan dosis biokompos 0 ton/ha, 3,5 ton/ha dan 7 ton/ha. Data dianalisis dengan analisis ragam dan dilanjutkan dengan uji berganda Duncan (Duncan's Multiple Range Test). Hasil penelitian menunjukkan bahwa pada tanah yang diberi biokompos kurang dari 7 ton/ha dan semua tingkat cemaran menunjukkan penurunan pertumbuhan dan produksi kedelai. Tanah yang diberi biokompos 7 ton/ha pada perlakuan konsentrasi cemaran nikel $25 \mathrm{ppm}$ menghasilkan produksi kedelai (jumlah polong isi) setara atau sama dengan tanah tanpa cemaran nikel. Konsentrasi nikel dalam biji kedelai pada tanah yang tercemar nikel $25 \mathrm{ppm}$ dengan diberi biokompos 7 ton/ha masih berada diatas ambang batas yang diijinkan.

Kata kunci: kedelai, cemaran nikel, biokompos
\end{abstract}




\section{PENDAHULUAN}

Indonesia sebagai negara agraris saat ini mulai bergeser menjadi negara industri. Seiring dengan pertumbuhan dan pembangunan di Indonesia mengakibatkan banyaknya industri, salah satunya adalah industri elektroplating. Limbah yang dihasilkan dari industri elektroplating dapat berupa padat, cair dan gas. Buangan limbah cair merupakan bagian terbesar karena air memiliki peranan penting pada setiap proses produksi. Limbah kimia yang dihasilkan dalam industri elektroplating (pelapisan logam) salah satunya yaitu nikel, dimana kandungan limbah cair nikel dari hasil elektroplating yaitu $63,10 \mathrm{mg} / \mathrm{L}$ (Yudo dan Said, 2005). Konsentrasi tersebut melebihi baku mutu yang telah ditetapkan menurut Kep. Men. Neg. L.H. No.: KEP-51/MENLH/10/1995 tentang Baku Mutu Limbah Cair Bagi Kegiatan Industri dimana limbah cair nikel sebesar $1,00 \mathrm{mg} / \mathrm{L}$.

Limbah nikel yang terakumulasi terus menerus dalam tanah dapat memberikan pengaruh buruk terhadap lahan pertanian yaitu pencemaran lingkungan atau terjadi degradasi lahan. Adanya industri elektroplating mengakibatkan banyaknya limbah atau cemaran industri yang mengakibatkan kerusakan pada tanah, air serta udara. Lahan pertanian yang tercemar oleh limbah industri menyebabkan terjadi penurunan $\mathrm{pH}$ tanah yaitu kisaran 4,3 - 5,5, tingginya kandungan $\mathrm{Al}^{3+}$, kandungan bahan organik rendah, ketersediaan hara N, P, K, Ca dan Mg rendah, serta kemampuan tanah mengikat air rendah (Budhi dan Aminah, 2010). Limbah cair tersebut secara tidak langsung akan masuk ke dalam badan air, sehingga apabila penggunaan air sungai tersebut menyebabkan akumulasi logam berat dalam tanah yang dan bersifat racun bagi tanaman (Gunawan et al.., 2015).

Menurut UNECE (United Nations Economic Commissions for Europe) bahwa konsentrasi nikel maksimum pada tanah pertanian yaitu $100 \mathrm{mg} / \mathrm{kg}$ dan di air tanah $20 \mu \mathrm{g} / 1$ (Gaillardet et al. 2005). Tingginya nikel dalam tanah tentu akan menyebabkan terjadi perubahan fisiologi dan gejala toksisitas antara lain klorosis dan nekrosis, serta tergangggunya fungsi membrane sel. $\mathrm{Ni}^{2+}$ berperan penting dalam aktivasi H-ATPase dan komposisi lipid. Terganggunya fungsi membran sel diakibatkan oleh ion logam berat mampu berikatan dengan kelompok protein dan bagian hidroksil dari fosfolipid sehingga akan menyebabkan kerja ion $\mathrm{K}^{+}$yang terdapat dalam membrane sel terganggu (Matraszek et al., 2016).

Kedelai merupakan tanaman kaya protein nabati dengan harga yang relatif terjangkau oleh masyarakat Indonesia. Kementerian Pertanian telah mencanangkan adanya swasembada kedelai pada tahun 2020, disamping swasembada tanaman pangan seperti jagung dan padi. Berdasarkan data BPS (2018) bahwa Jawa sebagai sentra kedelai di Indonesia pertumbuhan produksi kedelai rendah yaitu hanya $23,66 \%$ atau produksi kedelai hanya 130.525 ton sehingga perlu adanya impor kedelai sekitar 2,67 ton untuk mencukupi kekurangan kedelai dalam negeri. Hal ini dimungkinkan faktor yang mempengaruhi rendahnya produksi kedelai sala satunya adalah rusaknya lahan pertanian akibat limbah industri.

Upaya untuk mengatasi cemaran nikel di lahan pertanian perlu adanya pemberian adsorben. Adsorben adalah zat padat yang dapat menyerap komponen tertentu berupa ion maupun senyawa karena memiliki jumlah pori-pori terbuka dalam jumlah yang besar (Langenati et al.., 2012). Adsorben yang dapat diberikan berupa kompos, zeolit, dan senyawa organik lain yang dapat mengikat polutan dalam tanah. Adsorben yang digunakan dalam penelitian ini adalah biokompos, campuran antara biochar dan kompos. Ndor et al. (2016) memaparkan bahwa biochar sekam padi $120 \mathrm{~g}$ mampu menurunkan kandungan nikel sebesar $0,53 \mathrm{mg} / \mathrm{kg}$ namun tidak mampu menurunkan konsentrasi nikel pada tanaman bayam (Amaranthus cruentus). Biochar mampu menurunkan nikel tersedia di tanah sebesar 37,3 $\mathrm{mg} / \mathrm{kg}$ akan tetapi belum mampu menurunkan serapan nikel pada tanaman jagung ( $\mathrm{Zia}$ ur Rehman et al., 2016). Kompos yang diinokulasi dengan inokulum mikoriza arbuskular mampu menurunkan kandungan nikel pada akar dan biji kacang polong masing-masing sebesar 65,60 dan $71,46 \%$ (Nafady et al., 2017). Pemberian adsorben biokompos mampu menurunkan kadar serapan cemaran logam berat pada tanaman dikarenakan dalam biochar juga mengandung $\mathrm{C}$-organik yang tinggi untuk tanaman serta penggunaan kompos mampu memperbaiki struktur tanah karena adanya senyawa organik dalam kompos yang dapat 
meningkatkan kesuburan tanah terutama sifat fisik tanah.

Penelitian ini bertujuan untuk mengkaji respon pertumbuhan tanaman kedelai, produksi dan kualitas kedelai pada berbagai konsentrasi ion logam nikel dan pemberian biokompos.

\section{MATERI DAN METODE}

Penelitian ini dilaksanakan dari bulan November 2018 s/d Februari 2019 di Laboratorium Terpadu dan Rumah Kasa Balingtan, Pati, Jawa Tengah. pengamatan. Tahap pertama yaitu persiapan media tanam dilakukan dengan menimbang tanah seberat $7 \mathrm{~kg}$ kemudian dimasukkan ke dalam pot. Tanah yang digunakan berasal dari Kabupaten Bantul dengan jenis tanah yaitu inseptisol. Tanah di dalam pot diambil sedikit sebagai sampel untuk analisis tanah.

Tahap perlakuan, pot yang sudah berisi dengan media tanam kemudian dikontaminasi dengan larutan nikel sesuai perlakuan. Larutan ion logam nikel dibuat dengan cara serbuk nikel $\mathrm{NiSO}_{4}$ sesuai perlakuan dilarutkan ke dalam 1 liter aquades (masing-masing 0,6 g/pot (setara 25 $\mathrm{ppm}), 1,2 \mathrm{~g} /$ pot (setara $50 \mathrm{ppm}), 1,8 \mathrm{gram} / \mathrm{pot}$ (setara $75 \mathrm{ppm}$ ) dan 2,4 gram (setara $100 \mathrm{ppm}$ )).

\section{Materi}

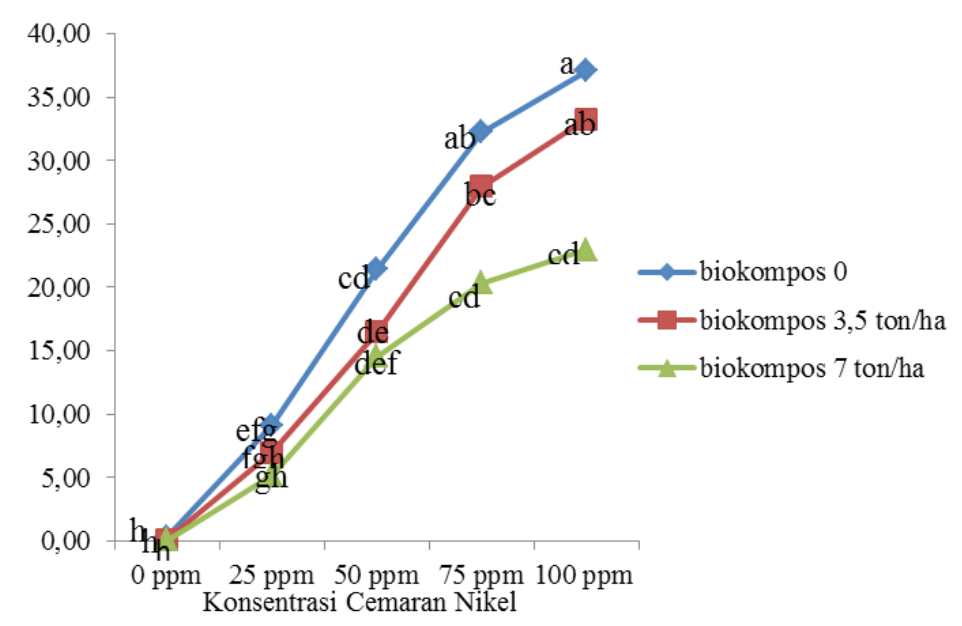

Ilustrasi 1. Grafik Interaksi Konsentrasi Nikel tersedia dalam Tanah

Bahan yang digunakan dalam penelitian ini adalah tanah, serbuk nikel $\mathrm{NiSO}_{4}$, biji kedelai varietas grobogan, biokompos, aluminium foil, pupuk Urea, pupuk TSP, pupuk $\mathrm{KCl}$, amplop dan plastik. Alat yang digunakan dalam penelitian ini yaitu pot sebanyak 45 buah, timbangan manual kapasitas $20 \mathrm{~kg}$, timbangan analitik, cangkul, alat siram, penggaris, cetok, label, ayakan, oven, motar, shaker, nampan, Atomic Absorbion Spektrophotometri (AAS), serta kamera.

\section{Metode}

Penelitian dilakukan dalam beberapa tahap yaitu tahap persiapan media tanam, perlakuan, penanaman, pemeliharaan, pemanenan dan
Serbuk nikel yang telah ditimbang sesuai dengan dosis perlakuan kemudian masing-masing dilarutkan dalam 1 liter aquades kemudian diaduk sampai larutan tersebut homogen. Pengaplikasiannya larutan ion nikel pada tanah dengan cara dituangkan sedikit demi sedikit kemudian diaduk rata. Tanah kemudian diinkubasi \pm selama 1 bulan dengan cara diberi air sampai kapasitas lapang dan pengadukan setiap hari. Pengadukan bertujuan agar cemaran nikel dalam tanah menjadi homogen Pengaplikasian biokompos dilakukan setelah inkubasi dengan cara mencampurkan biokompos sesuai dengan dosis perlakuan. Setelah penambahan biokompos pada media tanam, kemudian diambil sampel tanah 
untuk dianalisis logam pada tanah. Selanjutnya dilakukan penanaman dengan membuat lubang tanam dengan kedalaman $3-5 \mathrm{~cm}$ kemudian dimasukkan benih kedelai dan ditutup kembali dengan tanah.

Tahap perawatan dilakukan dengan menyiram tanaman setiap hari dan pengendalian OPT pada pertumbuhan tanaman kedelai. Pemupukan dilakukan menggunakan SP-36 sebanyak 1,0662 g/pot (setara $80 \mathrm{~kg} / \mathrm{ha}$ ) diberikan 2 kali yaitu $1 / 3$ saat tanam dan $2 / 3$ saat berumur 4 MST (Minggu Setelah Tanam), KCl sebanyak $1,3373 \mathrm{~g} /$ pot (setara $100 \mathrm{~kg} / \mathrm{ha}$ ) diberikan 2 kali yaitu $1 / 3$ saat tanam dan $2 / 3$ saat berumur 4 MST (Minggu Setelah Tanam) dan pupuk SP-36 sebanyak $4,1807 \mathrm{~g} /$ pot (setara $250 \mathrm{~kg} / \mathrm{ha}$ ) diberikan 1 kali yaitu saat tanam. Pemupukan dilakukan dengan menebar pupuk di sekeliling tanaman kemudian ditimbun dengan tanah. Pemanenan kedelai varietas grobogan dilakukan pada umur tanaman 79 HST atau ditandai dengan menguningnya daun pada tanaman tersebut. perlakuan yaitu yaitu tanpa pemberian biokompos atau kontrol $\left(\mathrm{A}_{0}\right)$, pemberian biokompos 3,5 ton/ha $\left(\mathrm{A}_{1}\right)$ dan pemberian biokompos 7 ton/ha $\left(\mathrm{A}_{2}\right)$. Kombinasi perlakuan sebanyak 15 dengan ulangan 3 kali, sehingga terdapat 45 pot/unit percobaan. Data yang diperoleh kemudian dianalisis ragam (uji F) untuk melihat pengaruh perlakuan dan kemudian dilanjutkan dengan uji jarak berganda Duncan pada taraf 5\% untuk melihat perbedaan antar perlakuan.

\section{HASIL DAN PEMBAHASAN}

\section{Konsentrasi Nikel (Ni) Tersedia dalam Tanah}

Hasil analisis menunjukkan bahwa perlakuan konsentrasi cemaran nikel dan biokompos masingmasing berpengaruh nyata $(\mathrm{P}<0,05)$ terhadap konsentrasi nikel tersedia dalam tanah dan terdapat interaksi antara dua faktor terhadap konsentrasi nikel tersedia dalam tanah (Ilustrasi $1)$.

Tabel 1. Tinggi tanaman kedelai akibat berbagai konsentrasi cemaran nikel dan dosis biokompos

\begin{tabular}{|c|c|c|c|c|}
\hline \multirow{2}{*}{$\begin{array}{c}\text { Konsentrasi } \\
\text { Cemaran Nikel }\end{array}$} & \multicolumn{3}{|c|}{ Biokompos } & \multirow{2}{*}{ Rata-rata } \\
\hline & 0 & 3,5 ton/ha & 7 ton/ha & \\
\hline \multicolumn{5}{|c|}{ 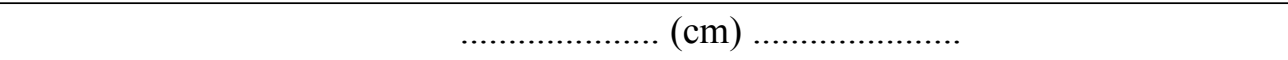 } \\
\hline $0 \mathrm{ppm}$ & 53,05 & 68,48 & 72,58 & $64,71^{\mathrm{a}}$ \\
\hline $25 \mathrm{ppm}$ & 53,27 & 48,57 & 56,55 & $52,79^{\mathrm{b}}$ \\
\hline $50 \mathrm{ppm}$ & 37,10 & 56,25 & 57,82 & $50,39^{\mathrm{b}}$ \\
\hline $75 \mathrm{ppm}$ & 36,80 & 44,10 & 43,20 & $41,37^{\mathrm{c}}$ \\
\hline $100 \mathrm{ppm}$ & 25,68 & 31,85 & 34,25 & $30,59^{\mathrm{d}}$ \\
\hline Rata-rata & $41,18^{\mathrm{b}}$ & $49,85^{\mathrm{a}}$ & $52,88^{\mathrm{a}}$ & \\
\hline
\end{tabular}

Superskrip yang berbeda pada baris dan kolom rata-rata menunjukkan perbedaan nyata pada taraf $\alpha=5 \%$.

\section{Rancangan Percobaan dan Analisis Data}

Penelitian dilaksanakan dengan menggunakan Rancangan Acak Lengkap (RAL) pola faktorial $5 \times 3$ dan diulang sebanyak 3 kali. Faktor pertama adalah konsentrasi cemaran nikel dengan 5 taraf perlakuan yaitu kontorol atau tanpa cemaran $\left(\mathrm{B}_{0}\right)$, cemaran 25 ppm $\left(\mathrm{B}_{1}\right)$, cemaran $50 \mathrm{ppm}\left(\mathrm{B}_{2}\right)$, cemaran 75 ppm $\left(\mathrm{B}_{3}\right)$ dan cemaran $100 \mathrm{ppm}\left(\mathrm{B}_{4}\right)$. Faktor kedua adalah dosis biokompos dengan 3 taraf
Interaksi antar dua faktor menunjukkan bahwa konsentrasi cemaran nikel dengan penambahan biokompos berpengaruh nyata terhadap konsentrasi nikel tersedia dalam tanah, dimana konsentrasi nikel tersedia dalam tanah mengalami peningkatan dengan penambahan konsentraasi cemaran nikel, dan namun menurun dengan penambahan biokompos. Pada perlakuan konsentrasi cemaran nikel 0 - 50 ppm dengan adanya penambahan biokompos tidak menunjukkan perbedaan nyata terhadap 


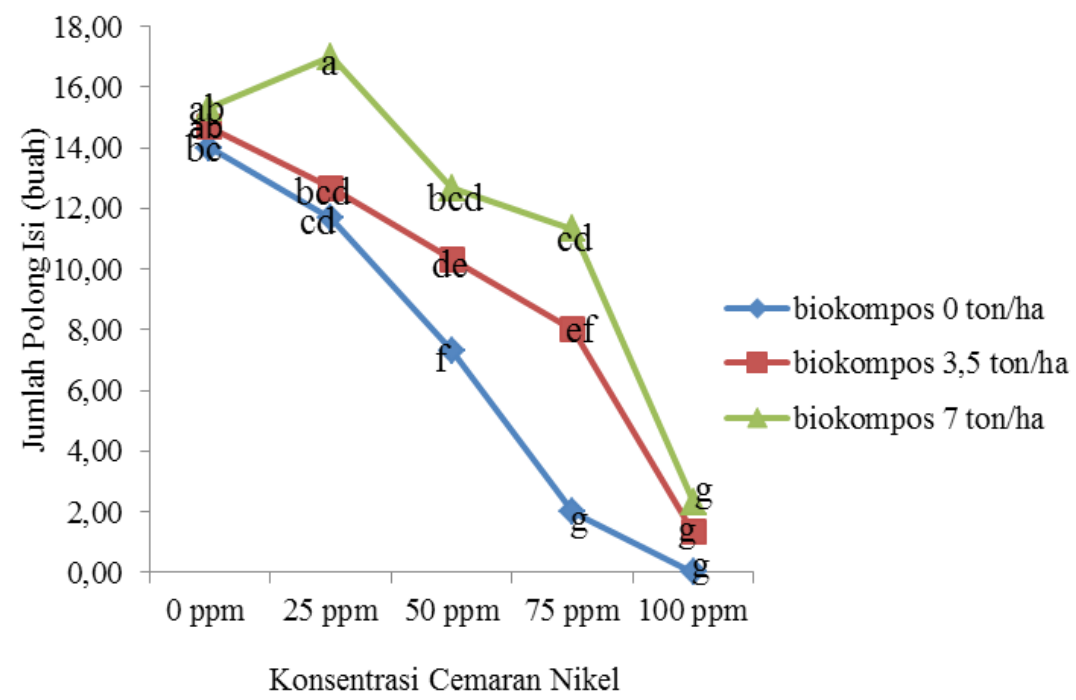

Ilustrasi 2. Grafik Interaksi Jumlah Polong Isi

kandungan nikel tersedia pada tanah. Konsentrasi cemaran nikel $75 \mathrm{ppm}$ dengan penambahan dosis biokompos 3,5 ton/ha tidak menunjukkan perbedaan nyata, namun mengalami penurunan kandungan nikel tersedia dalam tanah pada dosis biokompos 7 ton $/$ ha. Perlakuan konsentrasi cemaran nikel 100 ppm dengan adanya penambahan dosis biokompos 3,5 ton/ha tidak menunjukkan perbedaan nyata terhadap kandungan nikel tersedia pada tanah, namun mengalami penurunan kandungan nikel tersedia dalam tanah pada dosis biokompos 7 ton/ha. Semakin tinggi cemaran nikel yang diberikan ke tanah maka konsentrasi logam nikel tersedia dalam tanah akan semakin tinggi, sebaliknya penambahan dosis biokompos akan menurunkan konsentrasi logam nikel yang tersedia dalam tanah. Berdasarkan Ilustrasi 1. bahwa konsentrasi nikel tersedia dalam tanah pada perlakuan cemaran nikel 25 - 100 ppm baik tanpa biokompos maupun dengan penambahan dosis biokompos kandungan nikel tersedia berada diatas batas maksimum nikel dalam tanah. Hal ini sesuai pendapat Cela and Sumner (2002) yang menyatakan bahwa batas kristis nikel terekstrasi dalam tanah yaitu berkisar $2,5 \mathrm{mg} / \mathrm{kg}(2,5 \mathrm{ppm})$. Meningkatnya kandungan nikel tersedia dalam tanah dipengaruhi oleh daya sangga tanah, jika semakin tinggi daya sangga tanah maka konsentrasi nikel yang tersedia dan terlarut dalam tanah semakin rendah, sebaliknya jika tanah memiliki daya sangga tanah yang rendah logam tersedia dan terlarut dalam juga semakin tinggi. Purbalisa et al. (2018) menyatakan bahwa daya sangga tanah yang tinggi akan mempengaruhi kemampuan tanah dalam mengikat logam berat dalam tanah sehingga logam terlarut dalam tanah semakin rendah, sedangkan jika daya sangga tanah rendah maka logam terlarut dalam tanah semakin tinggi. Rendahnya konsentrasi nikel tersedia dalam tanah sebagai dampak penambahan dosis biokompos dikarenakan biokompos berperan sebagai pengikat logam berat. Beesley et al. (2014) menyatakan bahwa kombinasi biochar dan kompos sering digunakan untuk memperbaiki tanah yang tercemar oleh logam berat (loid), akan tetapi tidak direkomendasikan apabila diaplikasikan pada tanah yang tercemar logam As dalam konsentrasi tinggi.

\section{Tinggi Tanaman}

Hasil analisis menunjukkan bahwa perlakuan konsentrasi cemaran nikel dan biokompos masingmasing berpengaruh nyata $(\mathrm{P}<0,05)$ terhadap tinggi tanaman dan tidak terdapat interaksi antara dua faktor terhadap tinggi tanaman (Tabel 1).

Berdasarkan Tabel 1. peningkatan konsentrasi cemaran nikel menurunkan tinggi tanaman kedelai. Pertumbuhan tanaman menjadi terhambat karena ion $\mathrm{Ni}^{2+}$ terakumulasi dalam tanaman dengan jumlah yang berlebih dan menyebabkan toksisitas pada tanaman tersebut. 
Tabel 2. Bobot biomassa tanaman akibat berbagai konsentrasi cemaran nikel dengan pemberian biokompos

\begin{tabular}{|c|c|c|c|c|}
\hline \multirow{2}{*}{$\begin{array}{c}\text { Konsentrasi } \\
\text { Cemaran Nikel }\end{array}$} & \multicolumn{3}{|c|}{ Biokompos } & \multirow{2}{*}{ Rata-rata } \\
\hline & 0 & 3,5 ton/ha & 7 ton/ha & \\
\hline \multicolumn{5}{|c|}{$\ldots \ldots \ldots \ldots \ldots \ldots \ldots \ldots . .($ gram $)$} \\
\hline $0 \mathrm{ppm}$ & 4,76 & 6,28 & 6,46 & $5,83^{\mathrm{a}}$ \\
\hline $25 \mathrm{ppm}$ & 2,83 & 5,02 & 5,67 & $4,51^{\mathrm{b}}$ \\
\hline $50 \mathrm{ppm}$ & 2,00 & 3,18 & 3,23 & $2,80^{\mathrm{c}}$ \\
\hline $75 \mathrm{ppm}$ & 2,10 & 2,80 & 2,99 & $2,63^{\text {cd }}$ \\
\hline $100 \mathrm{ppm}$ & 1,06 & 1,88 & 2,39 & $1,56^{\mathrm{d}}$ \\
\hline Rata-rata & $2,55^{\mathrm{b}}$ & $3,83^{\mathrm{a}}$ & $4,15^{\mathrm{a}}$ & \\
\hline
\end{tabular}

Superskrip yang berbeda pada kolom dan baris rata-rata menunjukkan perbedaan nyata pada taraf $\alpha=5 \%$

Toksisitas nikel pada tanaman mengakibatkan terjadinya penurunan pertumbuhan tanaman karena terhambatnya pembelahan sel pada meristem akar serta terganggunya fotosintesis dan respirasi (Bhalero et al., 2015). Penambahan biokompos 3,5 ton/ha mampu meningkatkan pertumbuahan tanaman kedelai, hal ini dikarenakan biokompos mampu menurunkan konsentrasi nikel tersedia dalam tanah serta mampu meningkatkan ketersedian unsur hara yang berperan dalam pertumbuhan tanaman kedelai. Biokompos mampu meningkatkan ketersedian unsur hara dari tanah yang diserap atau diadsorpsi oleh akar tanaman. Purnomo et al. (2017) menambahkan bahwa kompos dalam tanah mampu menyediakan unsur nitrogen $(\mathrm{N})$ bagi tanaman sehingga meningkatkan pertumbuhan vegetatif seperti batang, cabang dan daun.

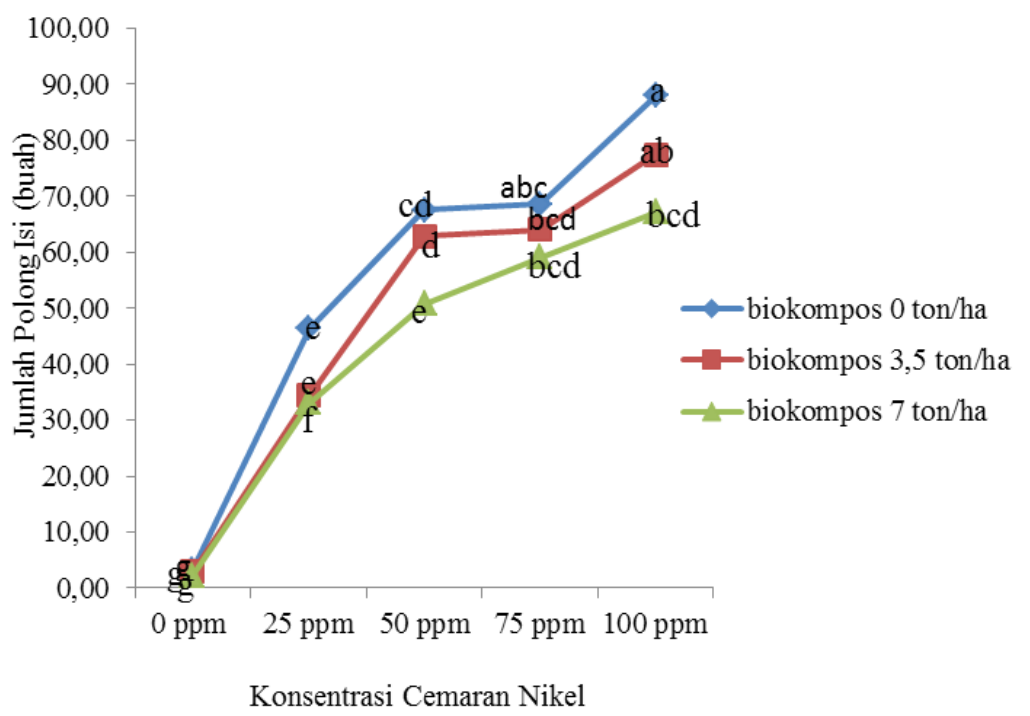

Ilustrasi 3. Grafik Interaksi Konsentrasi Nikel dalam Biji Kedelai 
Penelitian Sukartono dan Utomo (2012) mendapatkan informasi bahwa biochar mampu meningkatkan nilai KTK tanah serta meminimalisir resiko pencucian kation $\mathrm{K}^{+}$dan $\mathrm{NH}^{+}$.

\section{Jumlah Polong Isi}

Hasil analisis menunjukkan bahwa perlakuan konsentrasi cemaran nikel dan biokompos masingmasing berpengaruh nyata $(\mathrm{P}<0,05)$ terhadap jumlah polong isi dan terdapat interaksi antara dua faktor terhadap jumlah polong isi (Ilustrasi 2).

Interaksi antar dua faktor menunjukkan bahwa konsentrasi cemaran nikel dengan penambahan biokompos berpengaruh nyata terhadap jumlah polong isi/tanaman, dimana pada perlakuan konsentrasi cemaran nikel $25 \mathrm{ppm}$ dengan biokompos 7 ton/ha menghasilkan jumlah polong isi tertinggi sebesar 17,00 buah. Peningkatan dosis biokompos mengakibatkan jumlah polong isi yang dihasilkan semakin tinggi karena biokompos mampu mengikat logam berat dalam tanah sehingga logam tersebut tidak diserap oleh tanaman. Menurut Hidayat (2015) komponen basa dalam biochar $(\mathrm{Ca}, \mathrm{Mg}, \mathrm{K})$ dapat berperan sebagai netralisisasi kemasaman tanah sehingga kelarutan ion logam yang bersifat toxcic menjadi berkurang. Penambahan kompos berperan dalam mengurangi jumlah ion logam berat yang dapat diserap oleh tanaman menjadi bentuk yang tidak tersedia (karena terikat oleh bahan organik) sehingga meringankan terjadinya penumpukan logam akumulasi di jaringan tanaman (Huang et al., 2016). Terjadi penurunan jumlah polong isi pada perlakuan konsentrasi cemaran nikel $50-$ 100 ppm dengan adanya penambahan dosis biokompos. Hal ini menunjukkan pada konsentrasi cemaran nikel $50-100 \mathrm{ppm}$ nikel tersedia dalam tanah jumlah ion nikel tersedia dalam tanah lebih besar sehingga apabila ion tersebut terakumulasi secara berlebihan dalam jaringan tanaman dapat menurunkan poduksi dari tanaman kedelai tersebut. Faktor yang mempengaruhi hal tersebut adalah tingginya akumulasi ion $\mathrm{Ni}^{2+}$ dalam jaringan tanaman mengakibatkan proses fisiologi seperti translokasi hasil asimilat terhambat, sehingga jumlah polong hampa dihasilkan lebih banyak dibandingkan dengan jumlah polong isi. Hal ini dimungkinkan terjadinya kerusakan organel-organel tanaman sebagai dampak cemaran nikel. Ahmad dan Ashraf (2011) menyatakan bahwa terganggunya fotosintesis tanaman akibat nikel dikarenakan terjadinya kerusakan struktur dan fungsi kloroplas, kandungan klorofil dan fungsi kompleks protein fotosintetik.

\section{Bobot Biomassa Tanaman}

Hasil analisis menunjukkan bahwa perlakuan konsentrasi cemaran nikel dan biokompos masingmasing berpengaruh nyata $(\mathrm{P}<0,05)$ terhadap bobot biomassa tanaman dan tidak terdapat interaksi antara dua faktor terhadap bobot biomassa tanaman (Tabel 2).

Berdasarkan Tabel 2. dapat dilihat bahwa pada perlakuan konsentrasi cemaran nikel 100 ppm tanpa adanya penambahan biokompos menunjukkan bobot biomassa terendah dibandingkan perlakuan lain yaitu 1,06 gram. Hal ini menunjukkan bahwa tingginya cemaran nikel dalam tanah dapat menurunkan produksi biomassa tanaman kedelai. Menurut pendapat El-Shintinawy and El-Ansary (2000) bahwa konsentrasi nikel $>50 \mathrm{mM}$ pada tanaman kedelai menurunkan berat segar maupun berat kering dari biomasa tanaman. Hal ini dikarenakan cemaran nikel yang terakumulasi dalam tanaman mengganggu proses fisiologi tanaman sehingga menghambat pertumbuhan dan produksi tanaman. Didukung oleh pendapat Ishtiaq and Mahmood (2011) bahwa konsentrasi nikel diatas $50 \mathrm{mg} / \mathrm{kg}$ mampu menurunkan berat kering (dry matter) dari tiga jenis varietas kacang hijau.

Hasil DMRT pada Tabel 2 menunjukkan bahwa dosis biokompos menunjukkan perbedaan nyata terhadap bobot kering biomassa. Biokompos mampu meningkatkan berat kering brangkasan tanaman kedelai. Hal ini dikarenakan kedua bahan organik antara biochar dan kompos tersebut mampu bersinergi dengan baik sehingga mampu meningkatkan berat kering brangkasan yang dihasilkan. Liu et al. (2012) menyatakan bahwa sinergisme kompos dan biochar memberikan beberapa keuntungan antara lain (1) meningkatkan C-organik tanah dengan membentuk senyawa kompleks kompos biochar yang lebih stabil, (2) meningkatkan ketersedian hara melalui fiksasi $\mathrm{N}$ secara biologi, meminimalisasi terjadinya pencucian hara sehingga suplai hara tersedia dari kedua amelioran tersebut, dan (3) memperbaiki struktur tanah dan keseimbangan air dengan 
stabilisasi organ-mineral.

\section{Kandungan Logam Nikel dalam Kedelai}

Hasil analisis menunjukkan bahwa perlakuan konsentrasi cemaran nikel dan biokompos masingmasing berpengaruh nyata $(\mathrm{P}<0,05)$ terhadap kandungan logam nikel dalam kedelai dan terdapat interaksi antara dua faktor terhadap kandungan logam nikel dalam kedelai (Ilustrasi 3).

Interaksi antar dua faktor menunjukkan bahwa konsentrasi cemaran nikel dengan penambahan biokompos berpengaruh nyata terhadap konsentrasi nikel dalam biji kedelai, dimana pada perlakuan konsentrasi cemaran nikel 100 ppm tanpa adanya penambahan biokompos konsentrasi nikel dalam biji kedelai terbesar yaitu 87,99 ppm dibandingkan dengan perlakuan lain. Menurut Kristic et al. (2015) bahwa transportasi nikel dalam jaringan tanaman dengan xylem dan floem dan terjadi secara cepat dan efisien sehingga akan terakumulasi dalam biji tanaman. Biji kedelai yang layak untuk dikonsumsi yaitu terdapat pada perlakuan konsentrasi cemaran nikel 0 ppm tanpa biokompos, konsentrasi cemaran nikel $0 \mathrm{ppm}$ dengan biokompos 3,5 ton/ha serta konsentrasi cemaran nikel 0 ppm+biokompos 7 ton/ha yang masing-masing sebesar 3,36 ppm, $2,97 \mathrm{ppm}$ dan 2,24 ppm. Konsentrasi nikel tersebut cukup rendah karena tidak melebihi batas rekomendasi maksimum kadar nikel dalam jaringan tanaman yaitu sebesar $5 \mathrm{mg} / \mathrm{kg}$. Liu et al. (2011) memaparkan bahwa kadar Ni rata-rata dalam tanaman berkisar antara 0,1 hingga $5,0 \mathrm{mg} /$ $\mathrm{kg}$ bahan kering sedangkan nilai toksiknya melebihi $10 \mathrm{mg} / \mathrm{kg}$ bahan kering dianggap toksik bagi spesies atau kultivar yang sensitif terhadap cemaran nikel.

\section{KESIMPULAN}

Berdasarkan hasil penelitian yang telah dilakukan maka dapat disimpulkan bahwa konsentrasi nikel tersedia dalam tanah akibat cemaran ion logam dan pemberian biokompos berada diambang batas nikel dalam tanah. Tanah yang diberi biokompos kurang dari 7 ton/ha dan semua tingkat cemaran menunjukkan penurunan pertumbuhan dan produksi kedelai. Tanah yang diberi biokompos 7 ton/ha pada perlakuan konsentrasi cemaran nikel 25 ppm menghasilkan produksi kedelai (jumlah polong isi) setara atau sama dengan tanah tanpa cemaran nikel. Konsentrasi nikel dalam biji kedelai pada tanah yang tercemar nikel $25 \mathrm{ppm}$ dengan diberi biokompos 7 ton/ha masih berada diatas ambang batas yang diijinkan.

\section{DAFTAR PUSTAKA}

Ahmad, M. S. A. and M. Ashraf. 2011. Essential roles and hazardous effects of nickel in plants. Reviews of Environmental Contamination and Toxicology. 125-167.

Beesley, L., O. S. Inneh, G. J. Norton, E. M. Jimenez,T. Pardo, R. Clemente, and J. J. C. Dawson. 2014. Assessing the influence of compost and biochar amendments on the mobility and toxicity of metals and arsenic in a naturally contaminated mine soil. Enviromental Pollution. 186:195202.

Bhalerao, S. A., A. S. Sharma and A. C. Poojari. 2015. Toxicity of nickel in plants. Int. J. Pure App. Biosci. 3 (2):345-355.

BPS (Badan Pusat Statistik). 2018. Data Produksi Kedelai Menurut Provinsi Tahun 20142018.

Budhi, G. S. dan M. Aminah. 2010. Swasembada kedelai : antara harapan dan kenyataan. Forum Penelitian Agro Ekonomi. 28 (1) : $55-68$.

Cela, S. dan M. E. Sumner. 2002. Critical concentrations of copper, nickel, lead, and cadmium In soils based on nitrification. Communication in Soil Science and Palnt Analysis. 33(1-2):19-30.

El-Shintinawy, F. dan A. El-Ansary. 2000. Differential effect of $\mathrm{Cd}^{2+}$ And $\mathrm{Ni}^{2+}$ on amino acid metabolism in soybean seedlings. Biol Plant. 43:79-84.

Gaillardet, J., J. Viers dan B. Dupré. 2005. Trace elements in river waters. In : Drever JI (ed) Surface and ground water, weathering 
and soils. Treatise on Geochemistry, Oxford, Elsevier 5:225-227

Gunawan, R. Priyanto dan Salunik. 2015. Analisis lingkungan sekitar tambang nikel terhadap kualitas ternak sapi pedaging di Kabupaten Halamahera Timur. J. Ilmu Produksi dan Teknologi Hasil Peternakan. 3(1):59-64.

Hidayat, B. 2015. Remediasi anah tercemar logam berat dengan menggunakan biochar. J. Pertanian Tropik. 2(1):31-41.

Huang, M., Y. Zhu, Z. Li, B. Huang, N. Luo, C. Liu dan G. Zeng. 2016. Compost as a soil amendment to remediate heavymetalcontaminated agricultural soil: mechanisms, efficacy, problems, and strategies. Water Air Soil POllut. 227(359) :1-18.

Ishtaq, A. dan S. Mahmood. 2011. Phytotoxicity of nickel and its accumulation in tissues of three Vigna species at their early growth stages. Journal of Apllied Botany and Food Quality. 84 : 223-228.

Krstic, B., D. Stankovic, R. Igic, dan N. Nikolic. 2007. The potential of different plant species for nickel accumulation. Biotechnology \& Biotechnological Equipment. 21(4):431-436.

Langenati, R., R. Mordiono, D. Mustika, B. Wasito, dan Ridwan. 2012. Pengaruh jenis adsorben dan konsentrasi uranium terhadap pemungutan uranium dari larutan uranil nitrat. J. Tek Bhn. Nukl. 8(2):67122.

Liu, G., E. H. Simonne, dan Y. Li. 2011. Nickel nutrition in plants. IFAS Extension University of Florida.

Liu, J., H.Schulz, S. Brandl, H. Miehtke, B. Huwe, dan B. Glaser. 2012. Short term effect of biochar and compost on soil fertility and water status of a Dystric Cambisol in NE Germany under field conditions. Journal of Plant Nutrition and Soil Science, 175(5), 698- 707.

Matraszek, R., B. H. Nowak, S. Chwil dan M. Chwil. 2016. Macronutrient composition of nickel-treated wheat under different sulfur concentrations in the nutrient solution. Environmental Science and Pollution Research. 23(6):5902-5914.

Nafady, N. A., M. B. Mazen, M. M. M. Ahamed, dan O. A. Monsef. 2017. Transfer of nickel from polluted soil to Pisum sativum L. and Raphanus sativus L. under composted green amendment and native soil microbes. Agriculture, 63(2):52-66.

Ndor, E., O. J. Jayeoba dan J. I. Ogara. 2016. Effect of Biochar Amendment on Heavy Metals Concentration in Dumpsite Soil and their Uptake by Amaranthus (Amaranthus cruentus). JALSI, 9(1):1-7

Prasetiyono, E. 2015. Kemampuan kompos dalam menurunkan kandungan logam berat Timbal $(\mathrm{Pb})$ pada media budidaya ikan. J. Akuatika. 6(1):21-29.

Purbalisa, W., A. Hidayah, dan Sukarjo. 2018. Baku mutu arsen pada tanah inceptisol Grobogan dengan tanaman indikator padi. J. Tanah dan Sumberdaya Lahan. 5(1):621-627.

Purnomo, E. A., E. Sutrsino dan S. Sumiyati. 2017. Pengaruh variasi $\mathrm{C} / \mathrm{N}$ rasio terhadap produksi kompos dan kandungan kalium $(\mathrm{K})$, pospat $(\mathrm{P})$ dari batang pisang dengan kombinasi kotoran sapi dalam sistem vermicomposting. J. Teknik Lingkungan. 6(2):1-15.

Sukartono dan W. H. Utomo. 2012. peranan biochar sebagai pembenah tanah pada pertanaman jagung di tanah lempung berpasir (sandy loan) semiarid tropis Lombok Utara. Buana Sains. 12(1):91-98.

Yudo, S. dan N. I. Said. 2005. Pengolahan air limbah industri kecil pelapisan logam. 
JAI. 1(1): 17-29.

Zia ur Rehman, M., M. Rizwan, S. Ali, N. Fatima, B. Yousaf, A. Naeem, M. Sabir, H. R. Ahmad dan Y. Sik. 2016. Contrasting effects of biochar, compost and farm manure on alleviation of nickel toxicity in maize (Zea mays L.) in relation to plant growth, photosynthesis and metal uptake. Ecotoxicology and Environmental Safety. 133:218-225. 